\title{
is Research Square \\ Capitalizing on Fear and Failure: For-Profit Colleges Selling Themselves to the Poor
}

\section{Courtney Campbell}

University of Arizona

Regina Deil-Amen ( $\square$ reginad1@arizona.edu )

University of Arizona

Jessica Gjerde

University of Arizona

\section{Research Article}

Keywords: for-profit colleges, college choice, college access, admissions

Posted Date: August 13th, 2020

DOI: https://doi.org/10.21203/rs.3.rs-57119/v1

License: (c) (1) This work is licensed under a Creative Commons Attribution 4.0 International License.

Read Full License 


\section{Abstract}

This study explores the admissions encounter that prospective undergraduates experience at many forprofit colleges and universities (FPCUs). We consider how this encounter is shaped by intentional sales techniques and the implications of that approach for the college enrollment choices of low-SES and lowachieving students. Using the content of an admissions and recruitment staff training manual from a forprofit college with a publicly traded parent corporation and interviews from 47 students who went through the admissions and enrollment process at a for-profit college, we explore how recruiting practices are relevant to students' college choice and to our rethinking of how college choice operates for students who are very similar to community college populations. Our data reveal for-profit admissions representatives, despite their good intentions, are incentivized to work as institutional agents in service of the institution's profit motive at the expense of the student. FPCUs use admissions representatives to recruit prospective students by presenting the benefits of enrolling in a way that capitalizes on student anxieties, stress, and fear.

\section{Background}

This study explores what we refer to as the admissions encounter at for-profit colleges, which consists of the interactions between prospective students and admissions personnel with the ultimate goal of enrolling students. We consider how this encounter is shaped by intentional sales techniques and the implications of that approach for college enrollment choices, particularly for low-SES and low-achieving students. A wide variety of for-profit colleges and universities (FPCUs) currently operate in the United States, and their enrollment and recruiting practices have emerged as a significant player relevant to the college choices and pathways of growing numbers of students. The unfortunate consequence of this is that the high costs and low returns to for-profit enrollment generate student debt and repayment outcomes that are much worse compared to students enrolled in other types of colleges, contributing to the persistent student debt and loan default crisis (Armona, Chakrabarti, \& Lovenheim, 2020). Our research focuses on a large umbrella corporation that includes several well-known FPCUs, all of which are degree granting institutions offering certificates, associates, bachelors and, at a few locations, even graduate degrees. Although this particular case will probably differ from the practices of some smaller, independent 'mom-and-pop' for-profit colleges (Kinser, 2007), the practices of this FPCU are likely similar to many other larger for-profit companies that own multiple colleges.

\section{Background and Literature Review}

For-profit institutions increased enrollment by $127 \%$ between 2000 and 2016 compared to private nonprofit and public institutions whose enrollments increased by $27 \%$ and $25 \%$, respectively (NCES, 2018). The rapidly growing for-profit sector now enrolls $13 \%$ of all undergraduates (NCES, 2017). A disproportionate number of these students are working adults, low-income, and racial/ethnic minorities (Deming, Goldin \& Katz, 2011; Holland \& DeLuca, 2016). In fact, students attending FPCUs are more similar to students attending community colleges than traditional four-year colleges and universities 
(Tierney \& Hentschke, 2007). Why are so many lower-income students choosing this option, and why have FPCUs been neglected in the literature? An important driver of the enrollment numbers at for-profit colleges are the aggressive tactics used by admissions departments, which have been well documented by a 2012 Senate Report (U.S. Senate Committee on Health, Education, Labor, and Pensions (HELP), 2012) and featured frequently in the general media (Blumenstyle, 2011; Blumenstyle, 2012; Golden, 2010; Herbert \& Hustad, 2013; Kirkham, 2011; Shireman \& Miller, 2020). Research on this topic demands attention if the rising enrollment rates at for-profit institutions that too often result in higher debt and loan defaults are to be understood. With a few exceptions, higher education researchers who have qualitatively studied this enrollment phenomenon are scarce (DeLuca, Clampet-Lundquist, \& Edin, 2016; Holland \& DeLuca, 2016; Rosenbaum, Deil-Amen, \& Person, 2009). Therefore, studies that explore why students choose to attend these higher cost FPCUs and their decision-making experiences are few (Iloh \& Tierney, 2014).

The college choice literature has not only neglected the college choice of students who enroll in FPCUs, but it has also downplayed the role played by colleges as a key driver in such decisions. While models have been developed to illustrate what influences students' college choices (Cabrera \& La Nasa, 2001; Perna, 2006), most of the prior studies of college-choice have not included FPCU students (Avery \& Kane, 2004; Beattie, 2002; Bell, Rowan-Kenyon \& Perna, 2009; Bettinger, Long, Oreopoulos, \& Sanbonmatsu, 2012; Engberg \& Wolniak, 2009; Klasik, 2012; López Turley, Desmond \& Bruch, 2010; Pascarella, Pierson, Wolniak, \& Terenzini, 2004; Perna \& Titus, 2006; Turley, 2006). Therefore, the qualitative experiences of students who choose FPCUs has been generally overlooked. By ignoring the experiences of these students, we are also missing the realities of returning adult students and those whose lives do not reflect that of typical high school seniors.

Furthermore, much of the college choice literature has focused on individual student attributes and the ecology in which high school students are embedded rather than placing the actions of the higher education contexts at the forefront. This is not a minor oversight. As Rhoades (2014) points out, students' college choices are inevitably influenced by the choices that colleges make, yet, researchers tend to neglect this truth. Iloh (2018) constructs a new, more ecological model to analyze students' college going decisions that emphasizes the "context of information," which includes the type and delivery of information students can access. Iloh points out that students who have limited access to college-going information may be more heavily influenced by the targeted recruitment of certain colleges. In addition, Posecznick (2017) explores how a private, nonprofit college and the college's admissions staff navigate the college recruitment market. The institution and institutional actors working in admissions take an active role in carefully crafting a narrative when approaching potential students. Admissions staff in Posecznick's research acknowledge their potential to influence student choice during recruitment. Very few studies have focused on how colleges insert themselves into the process of college choice to shape student decisions and behaviors. In the present study, we bring the college to the forefront of college choice by analyzing how recruitment tactics at FPCU's are designed to shape students' enrollment decisions. 
Hentschke, Lechuga, and Tierney (2010) provide insights about how the organizational structure and processes of FPCUs facilitate their niche in the marketplace. Many FPCUs market their educational services and opportunities to students on the margins of higher education, including first-generation, lowincome, and underrepresented minority students (Hentschke et al, 2010; Holland \& DeLuca, 2016; McMillan Cottom, 2017), some of whom are targeted for marketing during high school events aimed at lower-achieving students with limited college knowledge (Holland, 2019a). The way students qualitatively experience these organizational processes, particularly at the point of choice, admission, and enrollment, has been left unexplored with only a few exceptions.

Two studies demonstrate how students who attend FPCUs gather information and make purposive choices about where to enroll in college. McMillan Cottom (2017) discusses college choice by naming time as a new commodity students trade for prestige, demonstrating how financial aid processes are intentionally easier to navigate at FPCUs, and linking the growth of credentialism with the decrease of onsite job training and education. This draws students into an "expedited launch into adulthood" (DeLuca et al., 2016) due to an eagerness to begin a career and make money, which creates for them an increased sense of urgency. lloh and Tierney (2014) explored the college choice process for students enrolling in nursing and surgical technician degree programs at a for-profit and community college. The authors found that students consider the short- and long-term costs and benefits of enrollment at each type of institution before choosing where to enroll.

Furthermore, other studies have shown that, as students consider where to enroll, their experience interacting with college websites, commercials, and personnel likely plays a crucial role. Iloh and Tierney's (2013) research team visited the websites of and made phone calls to both community colleges and FPCUs, posing as prospective students. They found that gathering information from each type of college is problematic in different ways. Community college websites provided more transparent and specific information than FPCU websites, particularly regarding cost, but opportunities to talk one-on-one with someone were lacking. FPCU websites excluded specific information on costs, but phone exchanges were much more customer service-oriented than phone calls to community colleges. Given that access to people with considerable knowledge of higher education is limited across their social networks, firstgeneration and low SES students are highly receptive to the brief, fast-paced messaging used in FPCU television advertisements, websites, and recruitment language (Holland \& DeLuca, 2016). These students are particularly receptive to for-profit college recruiters and their messaging due to their lower likelihood of having parents who went to college or friends with plans to attend 4-year colleges; lower parental involvement in their college-going decision than their peers in 2-year public or 4-year colleges; and lower educational aspirations and parental educational aspirations (Chung, 2012; Holland \& DeLuca, 2016). Potential for-profit college students often make enrollment decisions based on media ads, a positive experience with a recruiter, or familiarity with someone who is going or went to that particular college with little input from parents or counselors (Person \& Rosenbaum, 2006). This is consistent with other studies of the college choice process that find the number and variety of college options students consider dwindle as family SES, social and cultural capital, and access to college knowledge decreases (Cabrera \& La Nasa, 2001; McDonough, 1997; Vargas, 2004; Perna \& Titus, 2006). 
A host of other factors also draw low-income, first-generation, students of color to what for-profit colleges have to offer. The emphasis placed on standardized test scores in the college admissions process has been found to be a source of stress for disadvantaged students with college-going aspirations, discouraging minority students in particular from applying to selective colleges immediately after high school (Walpole, McDonough, Bauer, Gibson, Kanyi, \& Toliver, 2005). Furthermore, application and financial aid processes can be daunting for students who attend high schools without strong collegegoing cultures and the related social capital, guidance, and support needed to effectively negotiate the application, admissions, and enrollment processes at traditional institutions (McDonough, 1997). Many of these students find it especially difficult to translate their aspirations into admission and enrollment at a four-year institution, and they remove themselves from the process at various points during the stages between college goal-setting and actual enrollment (Roderick, Nagaoka, Coca, \& Moeller, 2008).

In addition to the informational and procedural obstacles of standardized testing and financial aid, students often face socio-emotional challenges that are overlooked in the research literature. Students who are not high achievers may experience substantial fear about their ability to meet the required academic expectations of college. In an ethnographic study, community college remedial students, in the absence of institutional intervention to acknowledge their fears and insecurities, were found to sabotage their own success in their attempts to avoid the failure they feared (Cox, 2009a, 2009b). Generally, lowerincome and first-generation university students, even those who are not placed into remediation, have also been found to anticipate that, unlike high school, they are on their own to meet college academic challenges and figure out how to be successful without anyone holding their hand. In other words, they do not have a sense of entitlement that staff and instructors will go out of their way to help them if they are struggling (Deil-Amen \& Martinez, 2015). Some of these students feel that proving they can succeed on their own without assistance is evidence of their worthiness, while needing help to succeed is a sign that they may not be 'college material' and perhaps do not belong in college (Deil-Amen, 2015).

The prior research noted above makes clear that the admissions practices of community colleges and FPCUs can powerfully shape the college search process for minoritized students, and further investigation of these practices is warranted. Our research builds on this prior scholarship as a starting point to consider student interpretations of admissions encounter interactions in more depth by acknowledging the role institutional agents and their practices have on college choice and centers those practices to gain a deeper understanding of why students choose FPCUs. We know very little about how these colleges, and the institutional actors representing them, deliberately structure their interactions with potential students. This leads to some important questions:

1. How are admissions encounters structured by for-profit institutions, and what dynamics are present within that set of interactions?

2. How do prospective students experience these admissions encounters, and how might these experiences differ from public or not-for-profit colleges/universities? 
Our conceptual framework helps to further situate these questions within the existing literature and offers a starting point from which we can develop theory related to the admissions encounter experience at FPCUs.

\section{Conceptual Framework}

A key difference in enrollment strategies for FPCUs and other institutions is the way FPCUs showcase their assets to recruit minoritized students rather than students showcasing their assets to gain admission. How do FPCUs successfully market their product to entice non-traditional and low-income students to enroll and spend so much money on their relatively high tuitions? We carefully consider the intersection of student circumstances when making these choices and the motivations of institutional agents employed by FPCUs during the admissions encounter. Regarding students, our lens recognizes that traditional college choice models wrongly conceptualize individual students as choosing among various college options while considering what assets they can showcase to be worthy enough to gain admission, or "get in" to the colleges of their choice (Cabrera \& La Nasa, 2001; Perna, 2006). In addition, a student's cultural knowledge and social network influence the evaluative frame they use when determining where to apply to college. Depending on the student's evaluative frame, the type of institutions included in a student's college application and selection process may not be ideal and could be problematic (Holland, 2019b). In reality, a majority of students who attend for-profit colleges identify themselves as lacking many of the assets that make them worthy of admission, and therefore, they tend to make more "haphazard" decisions about where to attend (DeLuca et al., 2016; Holland, 2013; Holland \& Deluca, 2016). This is because they are likely to be low-income, have less recognized social and cultural capital (Bourdieu, 1977), receive less guidance from counselors and parents, and have relatively low, or less-competitive markers of academic achievement (Chung 2012). Many may have tried to pursue college in the past and have not been successful. Therefore, due to their unimpressive GPA, test scores, extracurricular record, etc., they have a relatively weak 'package' to present to colleges or universities.

Our conceptual framework uses the concepts of institutional agent and fear to consider how admissions personnel at FPCUs capitalize on students' past educational challenges, limited college knowledge, and their current fear and failure to convince them to enroll. We utilize these concepts to better understand the agency FPCUs and their staff exert in shaping the encounter and students' decision-making processes.

The words that appear as text on the website of a for-profit college umbrella corporation illustrate how FPCU's recruit personnel with the best of intentions: "When you work at [name of company] you are changing lives through education - every day...If you're ready to start making a difference for working students and their families by helping them further their education, we're ready to talk to you." With intentions to improve the lives of students, these staff members are often motivated and willing to do the work of the organization. So how are they utilized? We consider how these personnel influence college decision-making and enrollment in their role as institutional agents (Stanton-Salazar, 2011, Bensimon, 2007) within the context of the corporation. We take seriously the agency that colleges have in shaping students' choice and trajectories. 
Institutional agents are actors with the authority, status, and power to provide a link between the students that the institution serves and the resources and information needed to navigate and succeed within an institution, such as a school or college (Stanton-Salazar, 2011). Admissions representatives are the first institutional actors that students encounter at for-profit colleges. However, admissions representatives provide resources and information in a way that restricts, or circumscribes, students' agency because the resources and information admissions representatives have the capacity to provide are designed to serve the interests of the institution. The concept of institutional agent must be adapted when considering the position of admissions representative. Generally, institutional agents prioritize the holistic success of students, and interactions with prospective students are chances for institutional agents to identify student needs and qualities to determine the fit between their institution and potential students. However, FPCU admissions representatives can be better thought of as "corporate agents," or agents who help to connect students to resources and information within the confines of their corporation's best interests (Campbell, 2019). The role of corporate agent becomes problematic when students do not have college knowledge to make value comparisons or when students assume the agent is working in their best interest as opposed to the college's interests.

In considering what makes students receptive to the idea of enrolling at FPCUs, we borrow Cox's (2009a, $2009 \mathrm{~b}$ ) notion that fear of failure can be a central component of the initial college-going experiences of lower-achieving students who have likely not succeeded in past school attempts. We engage in an exploration of the interactions and interpretations of those interactions that occur between FPCUs and potential students. The assumption that students act independently as they consider admissions options and formulate decisions is problematic. FPCUs may be playing a much more dominant role than we realize, compromising or heavy-handedly directing the student's agency.

Deil-Amen and Tevis (2010) define circumscribed agency as the phenomenon that occurs when students attempt to exert agency within situated contexts that limit or restrict broader understandings that might otherwise expand their interpretations of their opportunities and actions. It involves how social groups interpret and respond to their contexts, as well as individuals' self-efficacy within them. In the present study, our focus is on how the admissions tactics capitalize on students' habitus, which results in circumscribed agency for students choosing to enroll in FPCUs. The habitus of students, their "system of lasting, transposable dispositions which, integrating past experiences, functions at every moment as a matrix of perceptions, appreciations, and actions" (Bourdieu, 1977, p. 82-83), of course influences the parameters by which individuals perceive any given situation, interaction, or decision they encounter, based on their past experiences and socialization. Bourdieu highlights social class as a key determinant of habitus.

In our analyses, we consider FPCUs' prescribed recruitment and enrollment practices as they intersect with students' habitus, exposing how these institutions may be circumscribing student choice. We consider how a student's habitus and related social and cultural capital (Deil-Amen \& Tevis, 2010) inform their experience of the approach and behaviors of FPCUs and their staff. If the interaction between student and FPCU is guided by the institutional agent, does this make a student's college enrollment 
choice less about an individual choice and more about the nature of the relationship between the student and institutional agent? This intersection of how for-profit colleges frame the recruitment/admissions/enrollment process and how potential students receive and respond to it may be relevant for understanding why more and more students are choosing to attend FPCUs.

\section{Data And Methods}

Two sets of qualitative data are combined in this study. First, we coded and analyzed the training manual for admissions and recruitment staff of a nationally owned for-profit franchised corporation. Second, interviews from two related studies with students who went through the admissions/enrollment process at public, non-profit, and FPCUs were utilized to add their interpretations of their experiences with that process.

The for-profit corporation's training manual was analyzed with specific attention given to recurring concepts and information about the process of admissions. The training manual guides admissions representatives through the admissions encounter from a student's first inquiry to enrollment, explaining and directing manual readers through each step in the process laid out in detail. This includes a compliance guide with suggestions on how to answer questions about credit transfers, accreditation, etc., best practice sales tactics, lists of questions to be addressed when a potential student is on the phone, a questionnaire for the in-person interview, a step-by-step guide detailing the interview process, and tactics for overcoming student objections to enrollment.

Our coding strategy first applied descriptive, in vivo, and then concept coding (Saldaña, 2016) to the language used for training, putting particular emphasis on the methods and language suggested in the manual for how to address and what to say to potential students and families. An additional round of process coding was added to document how the manual framed the process potential students experience during the admissions encounter. For the process analysis, we also utilized the questioning technique suggested by Corbin and Strauss (2015). Questions included: What words and phrasing are to be used when speaking with students? What is the time frame from initial contact to enrollment? What resources do admissions representatives employ throughout the process? What is each interaction meant to accomplish? Some subcategories emerged that cross-cut each coding strategy, namely: 1) applying sales language, 2) identifying student success, including career opportunities, 3) defining quality, and 4) use of business language, which consisted of customer service and reputation. We then developed an axial coding strategy (Corbin \& Strauss, 2015) that considered the placement of particular language and concepts in the manual as well as their frequency to determine their relationship to the four subcategories.

The second data set includes interviews with a total of 47 students from two related studies involving students who attended FPCUs. The first of these related studies involved case studies of several community colleges, three not-for-profit two-year colleges, and four for-profit institutions in and around Chicago. Staff, administrators, faculty, and 125 students were interviewed who were involved with or 
enrolled in two-year accredited associate degrees programs in business, accounting, computer information systems, computer-aided drafting, court reporting and paralegal, office technology, electronics, engineering, and health programs. The present study utilizes only the interviews that were conducted with the 33 students from that study who had chosen to attend the FPCUs.

In the other study, slightly more than 1100 seniors were surveyed while attending five high-poverty high schools in Chicago. A carefully selected stratified subset of 110 of those students was chosen from the survey sample to optimize variation along several dimensions, including highest degree goals, their selfreported grades, race, knowledge about college, and the type of college they planned to attend. These students were interviewed during their senior year, again one to two years later, and then again two to three years later. The present study analyzed only the 14 students interviewed who transitioned to FPCUs.

The interview data for the 47 students total (33 from the first study and 14 from the second study) were entered into NVivo, a qualitative analysis package. Despite our use of theory from prior research, we attempted to bracket our ideas and assumptions, at least initially, in order to engage in coding and analysis techniques reflecting a grounded, inductive approach, as suggested by Corbin and Strauss (2015). We began with an open coding technique (Strauss \& Corbin, 1994), followed by in vivo, concept, and process coding to mirror the coding approach used for the training manual. Axial coding was then used to create a structured 'ranking' of concepts and sub-concepts so that core categories/themes could be identified to organize the final stages of the analysis and interpretation of the data.

\section{Discussion}

Traditionally, higher education researchers have highlighted the role of institutional agents in helping students access valuable knowledge, institutional networks, and resources regarding college-going (Stanton-Salazar, 2011, Bensimon, 2007). Our data reveal for-profit admission representatives, despite their good intentions, are incentivized to work as institutional agents in the service of the institution's profit motive at the expense of the student. Admissions representatives facilitate the intent of FPCUs by building relationships with potential students through what we call the admissions encounter. They create one-on-one connections with students for the purpose of influencing their college decision-making. This relationship begins at initial recruitment and continues until the student's enrollment process is completed and classes have begun. The student is meant to feel a sense of ownership and relationship throughout this protracted process as the institutional agent, acting on behalf of the FPCU, pushes enrollment to all students, whether it is in their best interest or not.

The admissions encounter includes very specific steps recommended by the training manual. Beginning with a questionnaire and ending with a recommendation to enroll, admissions representatives lead students through a prescribed process meant to end with the student signing an enrollment contract. We find the admissions and enrollment process at FPCUs may be quite different from what we know about the process students experience at other types of postsecondary institutions. 
First, the actual moment of the admissions encounter dominates the for-profit process, and that process is not only about securing admissions, it is a moment in which students are both admitted and enrolled. After having already been recruited through commercials, other forms of advertising, direct mail, and phone calls, students, during the actual admissions encounter, make a final choice about whether to enroll as well as begin the enrollment process. When a student comes to the college to gather information on their own or in response to an invitation, the admissions representative's goal is to enroll them before they leave. This stands in contrast to other more traditional institutions where the recruitment, choice, application, admission, acceptance, and enrollment process is much more protracted with distinct stages. In the for-profit college process, these final four stages are consolidated into one admissions encounter moment. Furthermore, the same staff person is assigned to lead any particular student into the admissions encounter - through a personal relationship developed in the recruitment stage that entices them to progress to enrollment and continues into the first days of attending classes.

Second, during this admissions encounter, sales techniques are central. The roles are reversed with the college selling itself to the student rather than the student trying to sell themselves to the college. Even though FPCUs ask students important questions in which they might appear to be merely inquiring about what the student values and desires, this process is not necessarily meant to facilitate student insights about their most appropriate college choice. Instead, the for-profit college staff use this gleaned information to employ targeted sales techniques to powerfully encourage the student's enrollment. These techniques can exploit the circumstances of students who lack the advocacy and social capital to make well-informed comparisons and decisions. Under the direction of the FPCU and their training manual, the admissions/recruitment staff representatives intentionally set the stage for the admissions process by capitalizing on student habitus, and they remain in control until enrollment is completed.

While elite colleges and universities often participate in recruitment activities, their audience and technique are very different from those of FPCUs (Soares, 2007; Karabel, 2006). Students who substantially delay college enrollment or who consider enrolling in a for-profit school tend to have lower aspirations for themselves, non-college educated parents with lower aspirations for them, and fewer friends with 4-year college plans (Holland, 2013; Holland \& DeLuca, 2016). Such circumstances make it reasonable to assume that students considering enrollment in FPCUs do not demonstrate the same level of informed advocacy as those choosing to attend other institutions or make enrollment decisions with constructs of college based on fear (Cox, 2009a). Based on our analyses of the interview data and the training manual, we find the admissions encounter at FPCUs is structured to capitalize on this lack of advocacy and fear and this is used to benefit the admissions representative to achieve the FPCU's goal of enrolling as many students as possible at the for-profit college. The aggressive enrollment tactics used by for-profit college admissions representatives are not accounted for in traditional college choice models. Admissions representatives emphasize the benefit of the FPCU by capitalizing on students' fears about more traditional institutions, such as large classes and little support from the institution, and the process of transitioning into college. These tactics work best when students lack involvement from parents or others who can advocate for them or help them do a thorough comparison of the variety of postsecondary options. 


\section{Initial Contact}

The admissions encounter could begin with a prospective student requesting more information from a website, calling the school after seeing or hearing a commercial, giving their information to a representative at a college fair or out in the community, or a variety of other ways. Immediately after first contact, in whatever form it takes place, the college aggressively pursues the student, rather than the student pursuing the college. A Government Accountability Office (GAO) report filed in 2010 found that undercover students who filled out website forms claiming to assist with finding a college match were bombarded with phone calls from for-profit college representatives. The highest volume of phone calls totaled 182 in 30 days for one of the undercover students (Kutz, 2010). The aggressive and persistent nature of the phone calls is a glance into the process that follows with the admissions representative steering the progression of the admissions encounter.

According to the training manual, once an admissions representative has a potential student on the phone the use of sales techniques begins, and hence the admissions encounter can be thought of as beginning at this moment. While the purpose of the phone call is to convince the potential student to come in for an admissions interview or even to merely look at the school, the identification of the student's needs begins immediately. In a case study comparing admissions and recruitment at for-profit and community colleges, lloh and Tierney (2013) found the for-profit college admissions representatives tended to respond to investigators' requests for information by engaging them in questions about hopes, dreams, and career aspirations. The questioning of potential students about such things is in line with the training manual's instruction to identify student needs. Once several needs have been identified, the admissions representative offers their own expertise and suggests they will be able to provide solutions for the student's needs/problems if they are willing to come in and meet at the college. Needs identification, defined in the manual as creating "the awareness of what your prospect has and what he or she wants, needs or desires," is the basis for much of the process that follows and is a vital part of the admissions representative's sales technique. Needs identification is first used during the phone call and again during the in-person interview.

\section{Sales Techniques}

The student's interview during the next phase of the admissions encounter is a crucial interaction, with admissions representatives taking a proactive role in the student's college choice. The admissions representative's job is to further decipher the values and needs/fears of the student and use those to build the institution's value from the student's perspective. The predominate focus of the training manual is the sales process which consists of identifying student needs by listening and creating value based on those needs. Analysis of the training manual found the greatest percentage of language used was "sales" language. For example, the training manual encourages admissions representatives to use a sales technique known as "peeling the onion," which encourages representatives to "peel" back the layers of protection surrounding a prospective student's emotional core to discover fears and areas in their life they view as problematic. The representative uses this to create a narrative that allows them to connect fears 
and problems described by the student to solutions offered by the FPCU (also called needs identification). The tactic exposes prospective students' fears, allowing the FPCU to become the solution. Aria, a Latina and first in her family to attend college, had little access to information about the college search and application process and only knew one person who went to college. Leaving her home and network were a major concern for her. Below Aria expresses a fear she has about living on her own. This is an opportunity for an admissions representative to expose a fear and create a need that the FPCU could potentially meet.

Interviewer: What are you thinking about in terms of the advantages and the drawbacks of living on campus [at a four-year college]? You sound like you are concerned about it.

Aria: I don't know. Living on my own. I won't know anyone.... I will be more lonely. I will have to start from zero.

Interviewer: Did you fill out any applications yet for any colleges?

Aria: I have not sent them. I don't know why. I have them all filled out, but I have not sent them. I am having doubts about it.

The need to remain close to home presented ample opportunity for the FPCU admissions representative to contact her, sell the commuting aspect and close-to-home location of the for-profit college, and convince her to enroll.

During the admissions encounter, if the student is unaware of what type of information they should be garnering from the representative or if the student lacks the social and cultural capital that would enable them to identify the strengths and weaknesses of the FPCU relative to other options, the institution is able to take advantage of this by using sales techniques to steer the student in the direction of the admissions representative's choosing. The ability of the representative to use the student's values and connect them with attributes of the college is a sales technique known as "partnership selling." This type of selling illuminates a specific feature of the institution and highlights how this feature benefits the student based on their individual needs. Bobby, an African-American student who had previously lived in public housing, moved from a non-profit college to a for-profit college based on the structure the for-profit offered, which Bobby saw as a benefit.

Bobby: It was just too much freedom for me. ... I kind of messed up and had to, you know, sit out for a little while. That's why I'm going to this school too. ... I mean it wasn't like I was a bad student, it was just I kind of fell behind a little bit, then I kind of got into this lazy mode and just wanted to work. That's why, that's what happened. I think it was just too much freedom for me...

While an FPCU may have many features that potential students could benefit from, "partnership selling" focuses only on the benefits of that particular college, excluding any information that might influence a student's college choice away from the FPCU. 
Generally, sales techniques and sales psychology commonly advocate appealing to basic needs and emotion to sell, especially fear or emotional pain (Caprino, 2013; Obringer, 2003), Different practitioners and authors have a variety of names for sales techniques from "persuasive selling" to selling according to human nature (Young, 2016). These techniques use the same method as the classic transactional sales technique often referred to as partnership selling, which identifies a need (the more connected to an intense emotion the easier the sale) and uses the product in question to fulfill that need (i.e. the need to live in a better neighborhood based on fear for family safety which can be linked to college enrollment by the prospect of a higher paying job) (Johnston \& Marshall, 2016). In other words, a potential student can protect their family by enrolling in college, which will lead to a better job and a better home.

Partnership selling can highlight how the for-profit institution is better suited to meet the student's needs than other institutions, including other for-profit institutions. The features available to use in partnership selling vary depending on the for-profit college, but for many programs, the length of the program is a draw for some students who fear the need to invest in schooling for a long period of years in order to obtain their degree, particularly if they need to enroll part-time. Diana had not planned on enrolling in college immediately after high school but decided to start right away after speaking with a recruiter:

Interviewer: So...why did you decide to choose this college?

Diana: Well, I really didn't research on it a lot, but I did, umm, there was someone who's at the school, and talked about it, and they told me, in three years, you'll get, y'know, associates. So they said it was something fast, y'know. I could start off, and then keep on going. So I start off, like, y'know, just to start off, and then later on, in the future, I'll go on to my bachelor's or something.

The admissions representative uses the feature of short program length to sell students who fear investing large amounts of time into school and believe they would need to invest large amounts of time at other institutions.

\section{Student Perceptions}

Student's lack of knowledge and perceptions of other institutions can be used by the admissions representative during the admissions encounter to steer the potential student toward enrollment at the FPCU. In the above case, the perception that an associate's degree obtained by most institutions is a lengthy ordeal is used. It is likely the prospective student will either not have enough knowledge of other institutions to refute the representative (Roderick et al, 2008) or have perceptions of other institutions that support the representative's portrait of these other options regardless of merit. Richard, a low-income, white, child of immigrants, was impressed by the welcome he received at the for-profit college versus his experience with a community college.

Interviewer: When you first came here to [name of for-profit] what was your experience when you walked in the door and tried to enroll? 
Richard: I liked it here. I had a good feeling... when I came here.

Interviewer. Did it feel different than [the community college] felt for you?

Richard: ...the admissions people were very nice and...they also showed the entire plan of the school. They gave me these packets right away. They were very forward in a nice way.

Interviewer: Is that something you didn't experience at [the community college]?

Richard: Yeah exactly. They didn't do that there.

Student's lack of knowledge and perceptions of other types of institutions provide an easy selling point for FPCUs. Also, minority students and students whose parents lack experience with college, who tend to engage in what Holland (2013) has deemed a haphazard college search, will lack information about colleges, criteria, and preferences. This makes them more vulnerable to the recruitment practices of FPCUs that capitalize on these knowledge gaps.

In approximately one-third of the interviews analyzed, students described feeling a personal connection to the institution that developed as a direct result of the pro-active approach taken by forprofit college representatives in their recruitment efforts and face-to-face admissions encounters. Unlike community colleges, which students said took a more passive and bureaucratic approach, for-profit college recruiters made extra efforts to be welcoming and enthusiastic, and admissions/enrollment staff took time with students to present information and convey the merits of attending their institution, often linking such conversations with students' interests, hopes, fears, and concerns. lloh and Tierney (2013) encountered similar findings during phone calls made to community colleges and FPCUs, where FPCUs were more likely to engage in conversation about the student, and community colleges were more likely to refer students to a website for information.

As Roderick et al (2008) demonstrate, students coming from under-resourced schools or schools without college-going cultures, or students without the social capital to effectively navigate college application and enrollment, frequently do not have someone advocating for them as they move through this process. Without adequate knowledge or someone who can navigate the process, students considering FPCUs will likely not apply or enroll at other types of institutions. Though these students might have relationships that offer support and encouragement of their aspirations, they likely lack informed advocacy. In other words, there is no one to verify if the FPCU will actually be beneficial. These students are more receptive to the influence of sales techniques such as partnership selling.

\section{Students Who Cannot "Sell" Themselves}

An important aspect of needs identification and partnership selling is the student's lack of confidence in their prior academic performance. During the admissions encounter at FPCUs, the students' values become the central measure of merit, rather than their grades, exam scores, or extracurricular activities. When students attempt the transition to college from an under-resourced school, they may have difficulty 
trying to sell themselves to colleges based on traditional measures of merit and worthiness. When FPCUs do the selling, students do not have to be concerned about their lack of impressive credentials. They only have to express what they value in postsecondary education to start a chain reaction of pro-active responses. Students are asked to consider what they believe will make college a successful experience, what is important to them in a potential school, and why they value education. The admissions encounter is structured to build upon the student's answers. Particularly powerful is the fact that FPCUs offer students the opportunity to attend an institution without the additional stress of college entrance exams, which can be a considerable barrier (Walpole et al, 2005). This is one more procedure that a student can forego. The admissions encounter at many FPCUs is focused on how the college is able to provide value to the student and not on how academically valuable the student is to the institution.

This situation is quite different from traditional colleges that send the message that students are unwanted if they cannot meet expected criteria, a message that reinforces student fears (Cox, 2009b). Along with these messages, low-income students may also feel greater stress about their transition into college than their high-income counterparts (Birnie-Lefcovitch, 2000). The FPCU sales tactics validate these negative perceptions of traditional institutions and demonstrate to potential students that their educational experience at a for-profit college will eliminate many of these negative, unwelcoming aspects that the student fears.

Enrollment at FPCUs does not require the same type of access to social capital as described by Roderick et al (2008) because the institution pursues the student, and in the admissions encounter, an admissions representative walks each prospective student through the process from the moment the student expresses interest until they are enrolled in class. In a study of Black students in higher education, Iloh and Toldson (2013) concluded that the ease of the for-profit college application process could be influencing the disproportionate enrollment of Black students in FPCUs. First-generation college students do not have to rely on their support systems or parents, who may lack experience, to navigate the process. The FPCU becomes the student's support system but with the agreement that the student enrolls at that particular FPCU.

\section{Financial Aid Assistance}

Students enrolling at FPCUs described that the financial aid planning and application assistance available to students helped relieve the fears they felt about the process. Diana expresses that her fears would have kept her from enrolling in college without the assistance provided by the FPCU:

Diana: I made an appointment...to go see the counselors over at the admissions office. I talked to them. They explained all the classes, y'know, how it's gonna work, y'know, financial aid and everything, and then I decided to do it. They helped me fill out everything, and she basically did all my scheduling... the hours and everything, the financial aid, and... she helped me through it...

Interviewer. Would you have applied for financial aid if they hadn't helped you? 
Diana: No. I'm afraid, I was scared, 'cause I don't know how it works. Y'know, and it's, like, really hard for me to pay out of my pocket, too, 'cause, y'know, we're not that rich. So...I don't think I would have. But they helped and they explained the process and everything, so...

When a student believes they are incapable of negotiating the financial aid process on their own, a forprofit institution becomes an attractive path. Many FPCUs walk students through the financial aid process step by step, even filling out paperwork for them. Oftentimes students are willing to make a commitment to enroll so that they can receive the procedural guidance about financing college that the FPCU has to offer.

The training manual specifies that the student is pushed to set an appointment with a financial aid officer within 72 hours of agreeing to enroll. The entire enrollment process happens quickly, leaving students little time to think about important aspects of college success such as college match or the price of the education they just purchased. The U.S. Senate HELP Committee report (2012), which reviewed FPCU practices, echoes these findings in their review of several FPCU training manuals. This may seem of little consequence to a student who is more pre-occupied with a hands-on experience that allows someone other than themselves to navigate the process for them, especially the financial aid process.

\section{Career as a Feature}

The training manual defines the FPCU's purpose as a means to a specific career. Much of the wording used in the manual centers around future careers of potential students, encouraging the admissions representative to focus on this feature. Career placement is an important aspect of the sales process which includes enticing literature such as lists of businesses where former students have been employed upon graduation. The details of employment (i.e. length and job description) are left out but students are sold on familiar names of employers and what they consider the fast track to positions at those companies. Half of the students interviewed chose FPCUs because of the appeal of a direct focus on a specific career (eliminating much of the 'irrelevant' general education students did not want to take) and condensed program lengths (i.e. 18 months to complete an AA degree). Johanna, a first-generation college Latina, acknowledges that her college search was narrowed in order to avoid general education courses.

Interviewer. Did you look at any other colleges?

Johanna: [shakes her head] I didn't want to go through all that Gen Ed stuff, at the big universities, like one year, two years of math. . .

Richard demonstrates how the for-profit used career opportunities as a feature during his admissions encounter:

Richard: I received all these packets here. They showed me a paper - all the companies you could work for in two years with the help of a program within [the for-profit college] which was in cahoots with those companies on the list. 
Any given feature of a career-oriented program can be highlighted as offering a benefit to the student depending on the student's expressed needs. Community colleges may offer similar programs at a lower cost, however, students may not have access to this type of information and are enticed by the career features sold by the admissions representative at the FPCU.

\section{Reputation}

The image of the FPCU in the local community is another important part of the enrollment process. The training manual emphasizes the FPCU's reputation/image as both a business and an educational facility which centers on the college's ability to provide career-driven education. Students regard the college's reputation as a benefit, as Bobby describes.

Interviewer: Have you ever thought about going to a community college for this kind of degree?

Bobby. No. ...because....it might hurt my reputation...it's just, you know...most jobs won't look at it if they never heard of that school so they probably think I don't know as much stuff. So at least I go to [name of for-profit] you know, since that's one of the good schools, they all are, you know...let's give him a job.

The image of the FPCU in the local community also allows FPCUs to use students' personal networks. For example, Bobby describes how he first heard about the for-profit college he was attending.

Bobby: Actually just by word of mouth. A lot of people say [name of non-profit college], a lot of people say [name of for-profit he attends], a lot of people saying [name of another college]. But most kept saying [name of his for-profit] cause of the [accelerated degree offered]." ... I was just like talking to my grandmother. She goes to church. She's the gospel lady, so...she was going to church, and they were saying yeah, [name of for-profit] was a good school to go to.

FPCUs make use of students' existing social networks even during the admissions encounter. Once the admissions interview has turned the prospective student into an enrollment, the training manual states the admissions representative should ask for referrals. Referrals are the largest source of new students, making students who are enrolling the business' marketing source to access their friends and family. Essentially, FPCUs are using the prospective students to generate leads for further marketing and recruitment. Consistent with chain migration models of college enrollment (Pérez \& McDonough, 2008; Person \& Rosenbaum, 2006), nearly all the students interviewed who chose to enroll in a for-profit college did so based on word-of-mouth referral from a for-profit college representative, a co-worker, a family member, friend, or community member within their family's social network.

In particular, students were more likely to feel intimidated about going to college when they had neither parents nor high school staff offering information about college or guiding their decision-making. Consequently, students felt more comfortable entering higher education when they had a personal connection to the institution. For over half of the students interviewed, that connection came in the form of a friend or extended family member who was enrolled or enrolling. FPCUs use referrals to their advantage by encouraging current and potential students to identify members of their community and 
support system who do not have a college degree. Johanna followed her cousins to her two-year for-profit college immediately after high school:

Interviewer: Did you look at any other schools when you were looking?

Johanna: [name of a four-year college].

Interviewer: Did you look at any other two-year schools?

Johanna: No.

Interviewer: Where did you get the information on [the for-profit]?

Johanna: From my cousin.

Interviewer: From your cousin. Does he or she go here?

Johanna: Yeah. My cousin and my brother.

Interviewer: They both go here?

Johanna: Yes.

Interviewer: When you looked at [four-year college], where did you get your information about that?

Johanna: My other cousin goes there.

Access to students' personal networks is paramount to FPCU admissions. The training manual shows that the institution is aware of this and taps into this network of resources right away. According to the training manual, not only do students provide the largest amount of potential enrollees who actually enroll with their referrals, but they also ensure they will be able to tell the students they contact that someone in their network has enrolled and recommended them to consider the college as well. This aligns with the behaviors of students who tend to depend on their personal networks in this way when choosing a college.

\section{Conclusions}

Our findings suggest that the admissions encounter at many FPCUs is a sales process effectively targeted to intervene in a student's decision-making regarding their choice of where to enroll. FPCUs recruit prospective students by presenting the benefits of enrolling in a way that capitalizes on what has been demonstrated in past research-the anxieties, stress, and overwhelming fear often experienced by students who are unfamiliar with college and have likely not succeeded in school in the past (Cox, 2009a). FPCUs can take advantage of student's prior college-going knowledge or lack thereof and how they receive college-going information. Consistent with lloh's (2018) new model of college "choice," which posits that the interacting contexts of information, opportunity, and time determine a student's college- 
going decision-making process, FPCUs can and do market to students who lack college-going knowledge and who have anxieties, fears, and limitations related to their college-going opportunities and timeline. The ways in which information is presented, by whom, and for what purposes has been overlooked in prior research. Our findings reveal how FPCUs intentionally intervene to reframe a prospective student's 'failure' in deliberate ways. The encounter is focused on listening to potential students to identify their needs and then matching those needs with solutions provided by the institution. The admissions staff are trained to sell the college to students as the solution to all their problems, fears, insecurities, and unfulfilled dreams. With a sales-driven enrollment process, students' needs can be conveniently directed into categories that link to solutions FPCUs can provide, condensing the college choice process into one or two meetings with an admissions representative. If a student lacks information, advocacy, or has misinformation about the transition into college, they may not recognize their needs could be better met elsewhere. During the admissions encounter, the admissions representative shares information in a way that steers potential students toward enrollment at the FPCU.

What is absent from this process and from the training manual are alternative solutions if the admissions representative is not confident the for-profit college will be able to meet the needs of the student. FPCUs offer students opportunities that may not exist at all traditional institutions such as flexible class schedules, clear career paths, or programs that have been shortened in length (all attributes of several of the programs offered at the FPCUs in this study). While it is quite probable that FPCUs are filling an unmet need, the FPCU may be a poor match for students in some circumstances. However, the admissions representative's job is to aggressively sell the school, not to offer admissions counseling about the best possible educational route for the student. Cox (2009a) also defines fear management strategies that students employ, such as postponing college, scaling down or redefining their aspirations, avoiding assessment, or quitting school altogether. Assuaging their fears and promoting seemingly ideal solutions, the admissions encounter strategies analyzed in this study capitalize on the insecurities and habitus of the students considering enrollment who fear the college process and doubt their ability to succeed in that process (Bourdieu, 1977; Cox, 2009b). Essentially, the admissions tactics utilized capitalize on students' habitus and the context of their decision-making process (Iloh, 2018) and result in circumscribed agency for students choosing to enroll in FPCUs, limiting their sense of available options and framing the for-profit college as the ideal option. In this scenario, institutional agents act as agents of the corporation, forwarding the corporation's interests (Campbell, 2019), many times at the expense of students' best interests rather than in the service of students' interests, particularly their financial interests.

The admissions encounter driven by FPCUs and their interests is not without consequences. FPCUs have been criticized extensively in the media and in reports for the debt burden of students who enroll in these colleges. The media narrative emphasizes how they have preyed on poor students who enroll and then leave college with large amounts of debt. Lawsuits have been brought against FPCUs for fraud and predatory student lending. Legislation has attempted to target particular programs that leave students with unmanageable debt after graduation. Lawsuits and legislation sought to protect students from predatory behavior by some FCPUs by limiting access to public funds for programs that do not meet 
certain requirements. However, understanding the student experience as they encounter aggressive sales tactics is important for understanding how some FPCUs are able to continue enrolling substantial numbers of low-income students.

Though the aggressive sales tactics some FPCUs use entice students to enroll in programs that may saddle them with undue debt, the admissions encounter at FCPUs is not without takeaways. Perhaps there are lessons to be learned from the active role that FPCUs encourage their institutional agents to take in connecting with incoming students. They have clearly been effective in recruiting low-income students to enroll in college. Institutional agents are able to build relationships with potential students and develop an understanding of what students value in a college education. These institutional agents also maintain their relationship through the recruitment and enrollment process, giving students a point of contact if they have questions or concerns. While the relationship is established in order to influence the college choice process, students feel welcomed as they enroll because they have already developed a connection with an institutional agent at their college.

It is likely that enrollment at FPCUs will continue to rise. This study focuses solely on students who decided to enroll at a for-profit college. In further research, it would be beneficial to explore the experiences of students who have either graduated or left FPCUs prior to graduation as well as those who decided not to enroll. The perspectives of these students have the potential to inform our understanding of both student experiences while enrolled in FPCUs and why some students with similar backgrounds to those who do enroll, choose not to enroll. It is imperative that academic scholars continue to explore and research this "sales" aspect of enrollment since it is impacting the trajectories of an increasing percentage of the United States' college-going population.

\section{Declarations}

Approval for the human subjects portion of this study was obtained from the Office for Research Protections at The Pennsylvania State University and the Human Subjects Protection Program at the University of Arizona.: The human subjects, or participants, in the study consented to participate, knowing that the data and findings would be published.

Competing Interests: The authors declare no competing interests.

\section{References}

Armona, L., Chakrabarti, R. \& Lovenheim, M.F. (2020). Student debt and default: The role of for-profit colleges (Report No. 811). New York: Federal Reserve Bank of New York.

Avery, C., \& Kane, T. J. (2004). Student perceptions of college opportunities. The Boston COACH program. In College choices: The economics of where to go, when to go, and how to pay for it (pp. 355-394). University of Chicago Press. 
Beattie, I. R. (2002). Are all" adolescent econometricians" created equal? Racial, class, and gender differences in college enrollment. Sociology of Education, 19-43.

Bell, A. D., Rowan-Kenyon, H. T., \& Perna, L. W. (2009). College knowledge of 9th and 11th grade students: Variation by school and state context. The Journal of Higher Education, 80(6), 663-685.

Bensimon, E. M. (2007). The underestimated significance of practitioner knowledge in the scholarship on student success. The Review of Higher Education, 30(4), 441-469.

Bettinger, E. P., Long, B. T., Oreopoulos, P., \& Sanbonmatsu, L. (2012). The role of application assistance and information in college decisions: Results from the h\&r block fafsa experiment*. The Quarterly Journal of Economics, 127(3), 1205-1242.

Birnie-Lefcovitch, S. (2000). Student perceptions of the transition from high school to university: Implications for preventative programming. Journal of the First-Year Experience \& Students in Transition, 12(2), 61-88.

Blumenstyle, G. (2012, January 22). Senator Takes Aim at FPCUs Reliance on Federal Money and Aggressive Recruiting of Veterans. The Chronicle of Higher Education.

http://chronicle.com/article/Senator-Takes-Aim-at/130426/

Blumenstyle, G. (2011, April 12). Accreditor's Probe of Questionable Recruiting Practices Continues at 3 FPCUs. The Chronicle of Higher Education. http://chronicle.com/article/Accreditors-Probe-of/127098/

Bourdieu, P. (1977). Outline of a Theory of Practice. New York: Cambridge University Press.

Cabrera, A. F., \& La Nasa, S. M. (2001). On the path to college: Three critical tasks facing America's disadvantaged. Research in Higher Education, 42(2), 119-149.

Campbell, C. (2019). Framing Students: A Study of Institutional Agents at For-profit and Community Colleges. Dissertation. University of Arizona.

Caprino, K. (2013, May 30). 10 Essential Selling Principles Most Salespeople Get Wrong. Forbes. http://www.forbes.com/sites/kathycaprino/2013/05/03/10-essential-selling-principles-most-salespeopleget-wrong/

Chung, A. S. (2012). Choice of for-profit college. Economics of Education Review, 31(6), 1084-1101.

Corbin, J., \& Strauss, A. (2015). Basics of qualitative research: Techniques and procedures for developing grounded theory. Sage.

Cox, R. D. (2009a). "It Was Just That I Was Afraid" Promoting Success by Addressing Students' Fear of Failure. Community College Review, 37(1), 52-80. 
Cox, R. D. (2009b). The college fear factor: How students and professors misunderstand one another. Harvard University Press.

Deil-Amen, R., \& Tevis, T. L. (2010). Circumscribed agency: The relevance of standardized college entrance exams for low SES high school students. Review of Higher Education: Journal of the Association for the Study of Higher Education, 33(2), 141-175.

Deil-Amen, Regina. 2015. “The 'Traditional' College Student: A Smaller and Smaller Minority and Its Implications for Diversity and Access Institutions" In Remaking College. (Eds Stevens, Mitchell \& Kirst, Michael). Stanford University Press.

Deil-Amen, Regina \& Guadalupe Martinez. 2015. "College for All Latinos? The Role of High School Messages in Facing College Challenges" Teachers College Record, 117(3), 1-50.

DeLuca, S., Clampet-Lundquist, S., \& Edin, K. (2016). Coming of Age in the Other America. Russell Sage Foundation.

Deming, D. J., Goldin, C., \& Katz, L. F. (2011). The For-Profit Postsecondary School Sector: Nimble Critters or Agile Predators? (No. w17710). National Bureau of Economic Research.

Engberg, M., \& Wolniak, G. (2009). Navigating disparate pathways to college: Examining the conditional effects of race on enrollment decisions. The Teachers College Record, 111(9), 2255-2279.

Golden, D. (2010, April 30). The Homeless at College. Bloomberg Business Magazine. http://www.businessweek.com/magazine/content/10_19/b4177064219731.htm

Hentschke, G. C., Lechuga, V. M., \& Tierney, W. G. (2010). For-Profit Colleges and Universities: Their Markets, Regulation, Performance, and Place in Higher Education. Stylus Publishing.

Herbert, M. \& Hustad, E. (2013, November 13). FPCUs: Perspective Students Need to Approach Them with Eyes Wide Open. MinnPost. http://www.minnpost.com/education/2013/11/profit-colleges-prospectivestudents-need-approach-them-eyes-wide-open

Holland, M. M. 2013. Unequal Playing Fields, Same Game: The College Application Process for Students at Diverse High Schools. Doctoral Dissertation, Cambridge, MA.: Department of Sociology Harvard University.

Holland, M. M. (2019a). Divergent Paths to College: Race, Class, and Inequality in High Schools. Rutgers University Press.

Holland, M. M. (2019b). Framing the Search: How First-Generation Students Evaluate Colleges. The Journal of Higher Education, 1-24. 
Holland, M. M., \& DeLuca, S. (2016). "Why Wait Years to Become Something?" Low-income African American Youth and the Costly Career Search in For-profit Trade Schools. Sociology of Education, 89(4), 261-278.

Iloh, C. (2018). Toward a new model of college "choice" for a twenty-first-century context. Harvard Educational Review, 88(2), 227-244.

Iloh, C., \& Tierney, W. (2013). A comparison of for-profit and community colleges' admissions practices. College and University, 2-12.

Iloh, C., \& Tierney, W. (2014). Understanding for-profit and community college choice through rational choice. Teachers College Record, 116(8), 1-34.

Iloh, C., \& Toldson, I. A. (2013). Black Students in 21st Century Higher Education: A Closer Look at ForProfit and Community Colleges (Editor's Commentary). The Journal of Negro Education, 82(3), 205-212.

Johnston, M. W., \& Marshall, G. W. (2016). Contemporary selling: Building relationships, creating value. Routledge.

Karabel, J. (2006). The chosen: The hidden history of admission and exclusion at Harvard, Yale, and Princeton. Houghton Mifflin Harcourt.

Kinser, K. (2007). Dimensions of corporate ownership in for-profit higher education. The Review of Higher Education, 30(3), 217-245.

Kirkham, C. (2011, February 08). For-Profit College Recruiters Taught to Use 'Pain,' 'Fear,' Internal Documents Show. Huff Post. http://www.huffingtonpost.com/2011/02/08/for-profit-college-recruitersdocuments_n_820337.html

Klasik, D. (2012). The college application gauntlet: A systematic analysis of the steps to four-year college enrollment. Research in Higher Education, 53(5), 506-549.

Kutz, G. D. (2010). FPCUs: Undercover Testing Finds Colleges Encouraged Fraud and Engaged in Deceptive and Questionable Marketing Practices. Testimony before the Committee on Health, Education, Labor, and Pensions, US Senate. GAO-10-948T. US Government Accountability Office.

López Turley, R. N., Desmond, M., \& Bruch, S. K. (2010). Unanticipated Educational Consequences of a Positive Parent-Child Relationship. Journal of Marriage and Family, 72(5), 1377-1390.

McDonough, P. M. (1997). Choosing colleges: How social class and schools structure opportunity. Suny Press.

McMillan Cottom, T. (2017). Lower Ed: The troubling rise of for-profit colleges in the new economy. New York: The New Press. 
Obringer, L. (2003, January 01). How Sales Techniques Work. http://money.howstuffworks.com/businesscommunications/sales-technique4.htm

Pascarella, E. T., Pierson, C. T., Wolniak, G. C., \& Terenzini, P. T. (2004). First-generation college students: Additional evidence on college experiences and outcomes. Journal of Higher Education, 249-284.

Perez, P. A., \& McDonough, P. M. (2008). Understanding Latina and Latino College Choice A Social Capital and Chain Migration Analysis. Journal of Hispanic higher education, 7(3), 249-265.

Perna, L. W., \& Titus, M. A. (2004). Understanding differences in the choice of college attended: The role of state public policies. The Review of Higher Education, 27(4), 501-525.

Perna, L. W. (2006). Understanding the relationship between information about college prices and financial aid and students' college-related behaviors. American Behavioral Scientist, 49(12), 1620-1635.

Person, A. E., \& Rosenbaum, J. E. (2006). Chain enrollment and college enclaves: Benefits and drawbacks of Latino college students' enrollment decisions. New Directions for Community Colleges, 2006(133), 5160 .

Posecznick, A. (2017). Selling hope and college: Merit, markets, and recruitment in an unranked school. Cornell University Press.

Rhoades, G. (2014). The Higher Education We Choose, Collectively: Reembodying and Repoliticizing Choice. The Journal of Higher Education, 85(6), 917-930.

Roderick, M., Nagaoka, J., Coca, V., \& Moeller, E. (2008). From High School to the Future: Potholes on the Road to College. Research Report. Consortium on Chicago School Research. 1313 East 60th Street, Chicago, IL 60637

Rosenbaum, J. E., Deil-Amen, R., \& Person, A. E. (2009). After admission: From college access to college success. Russell Sage Foundation.

Saldaña, J. (2016). The coding manual for qualitative researchers ( $3^{\text {rd }}$ ed.). Thousand Oaks, CA: Sage Publications

Shireman, R., \& Miller, K. (2020). Student debt is surging at for-profit colleges. The Century Foundation.

Soares, J. (2007). The Power of Privilege: Yale and America's Elite Colleges. Stanford: Stanford University Press.

Stanton-Salazar, R. D. (2011). A social capital framework for the study of institutional agents and their role in the empowerment of low-status students and youth. Youth \& Society, 43(3), 1066-1109. 
Strauss, A., \& Corbin, J. (1994). Grounded theory methodology. Handbook of qualitative research, 273285.

Tierney, W. G., \& Hentschke, G. C. (2007). New players, different game: Understanding the rise of for-profit colleges and universities. JHU Press.

Turley, R. N. L. (2006). When parents want children to stay home for college. Research in Higher Education, 47(7), 823-846.

U.S. Department of Education, National Center for Education Statistics. (2017). Figure 1: Changes over time percentage of undergraduates enrolled in for-profit postsecondary institutions by level of institution: 1995-96, 1999-2000, 2003-04, 2007-08, and 2011-12. Retrieved from U.S. Department of Education: https://nces.ed.gov/pubs2017/2017416.pdf

U.S. Department of Education, National Center for Education Statistics. (2018). Figure 4. Undergraduate enrollment in degree-granting postsecondary institutions, by control of institution: Fall 2000 through 2016. Retrieved from U.S. Department of Education:

https://nces.ed.gov/programs/coe/indicator_cha.asp

U.S. Senate. Committee on Health, Education, Labor, and Pensions. (2012) For-profit Higher Education: The Failure to Safeguard the Federal Investment and Ensure Student Success (S.Prt. 112-37). Washington: Government Printing Office, 2012.

Vargas, J. H. (2004). College knowledge: Addressing information barriers to college. Boston, MA: Education Research Institute.

Walpole, M., McDonough, P. M., Bauer, C. J., Gibson, C., Kanyi, K., \& Toliver, R. (2005). This Test is Unfair Urban African American and Latino High School Students' Perceptions of Standardized College Admission Tests. Urban Education, 40(3), 321-349.

Young, S. C. (2016). Brilliant Persuasion: Everyday techniques to boost your powers of persuasion. Pearson UK. 